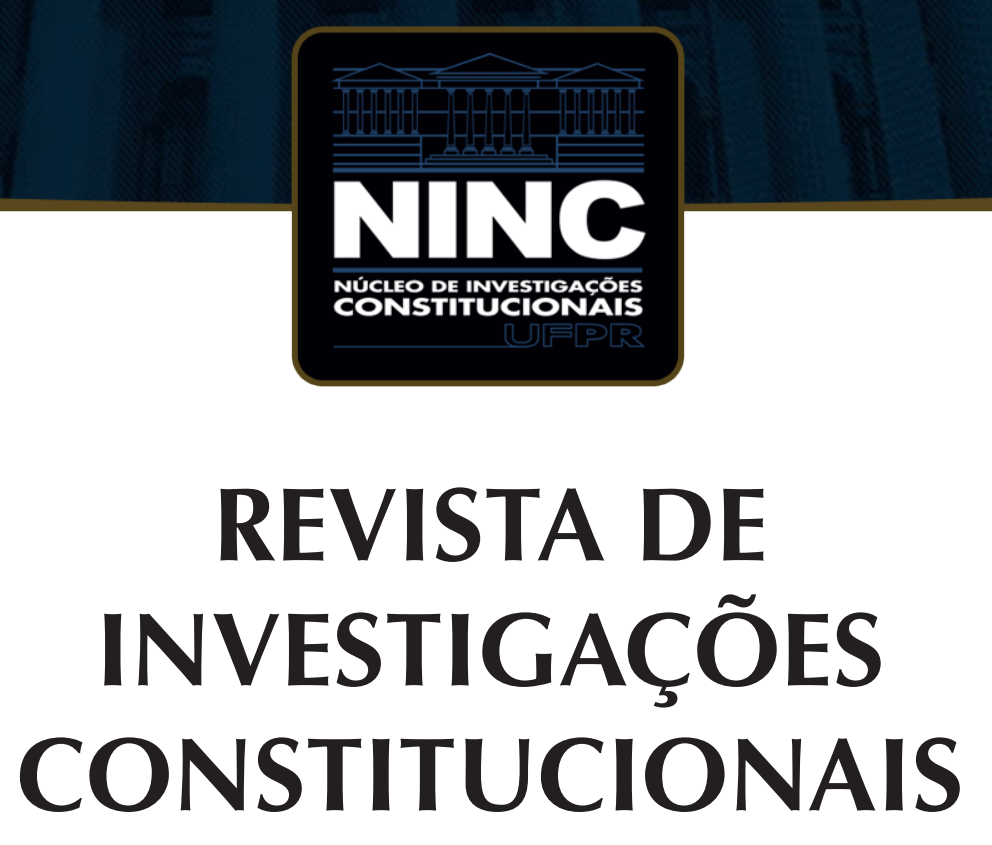

JOURNAL OF CONSTITUTIONAL RESEARCH

vol. 5 | n. 3 | setembro/dezembro 2018 | ISSN 2359-5639 | Periodicidade quadrimestral Curitiba | Núcleo de Investigações Constitucionais da UFPR | www.ninc.com.br 


\section{The Brazilian Constitution of 1988 and its ancient ghosts: comparison, history and the ever-present need to fight authoritarianism}

\section{A Constituição Brasileira de 1988 e seus fantasmas do passado: comparação, história e a sempre presente necessidade de lutar contra o autoritarismo}

\section{FERNANDO JOSÉ GONÇALVES ACUNHA*}

Centro Universitário de Brasília - UniCEUB (Brazil) fernandojgacunha@gmail.com

MOHAMED A.'ARAFA**

Indiana University School of Law (United States of America) Alexandria University Faculty of Law (Egypt) marafa@iupui.edu

\section{JULIANO ZAIDEN BENVINDO***}

Universidade de Brasília (Brazil) juliano@unb.br

Recebido/Received: 12.08.2018 / August 12 ${ }^{\text {th }}, 2018$ Aprovado/Approved: 30.08.2018 / August 30 ${ }^{\text {th }}, 2018$

\footnotetext{
Como citar esse artigo/How to cite this article: ACUNHA, Fernando José Gonçalves; 'ARAFA, Mohamed A.; BENVINDO, Juliano Zaiden. The Brazilian Constitution of 1988 and its ancient ghosts: comparison, history and the ever-present need to fight authoritarianism. Revista de Investigações Constitucionais, Curitiba, vol. 5, n. 3, p.17-41, set./dez. 2018. DOI: 10.5380/rinc.v5i3.60962.

* Professor of Constitutional Law at Centro Universitário de Brasília - UniCEUB (Brasília-DF, Brazil). PhD in Constitutional Law at University of Brasília (Brasília-DF, Brazil). MSc. at University of Brasília (Brasília-DF, Brazil). Graduated from Federal University of Paraná (Curitiba-PR, Brazil). E-mail: fernandojgacunha@gmail.com.

** Adjunct Professor of Islamic Law at Indiana University Robert H. McKinney School of Law (Indianapolis, United States of America). Assistant Professor of Criminal Law and Criminal Justice at Alexandria University Faculty of Law (Alexandria, Egypt). Doctor of Juridical Science (S.J.D.), 2013, Indiana University Robert H. McKinney School of Law. Master of Laws (LL.M.) in American Criminal Law and Criminal Justice, 2008, University of Connecticut School of Law (USA). Bachelor of Laws (LL.B.), 2006, Alexandria University, Faculty of Law ("English" Department) (Alexandria, Egypt). Visiting Scholar/Professor at Cornell Law School (Ithaca, United States of America) in 2018-2019. E-mail: marafa@iupui.edu.

${ }^{* * * *}$ Professor of Constitutional Law at University of Brasília (Brasília-DF, Brazil). PhD in Constitutional Law at Humboldt University (Berlin, Germany). PhD in Constitutional Law at University of Brasília (Brasília-DF, Brazil). MSc. at University of Brasília (Brasília-DF, Brazil). Gratuated from University of Brasília (Brasília-DF, Brazil). Research Fellow of the Brazilian National Council for Scientific and Technological Development (CNPq, n. 308733/2015-0). E-mail: juliano@unb.br.
} 


\section{Abstract}

Brazil is facing one of its most severe political crises since 2016 , with several impacts in its gradual process of democratization. In this context, the main argument in this work is that many of the ghosts that scary the Brazilian society in the Twenty-First century are direct heirs of an unresolved (pre-constitutional) past, whose risks can be strongly perceived and whose solution is an urgent task. Every time there is political turmoil and a disturbance to the rule of law in the country, the support for democracy seems to dwindle. In this vein, this article aims to explore such contradictions and difficulties and how they still represent a threat to the Brazilian democracy through an analysis dedicated to the complex and ambiguous relation that the Constitution (and various of the Brazilian institutions, like the Supreme Court) has (have) established with the military dictatorship that lasted from 1964 until 1985. The authoritarian ghosts that up until now haunts the Brazilian reality, though inevitable due to the compromises that underpin it and the practices that stubbornly replicate the past into the very present, have at least to be disclosed and, as such, challenged by a learning process that only a militant memory is capable of making us aware of.

Keywords: Brazilian Constitution; democracy; authoritarianism; military intervention; dictatorship.

\section{Resumo}

O Brasil enfrenta uma de suas crises políticas mais severas desde 2016, com vários impactos em seu processo gradual de democratização. Neste contexto, o principal argumento neste trabalho é que muitos dos fantasmas que assustam a sociedade brasileira no século XXI são heranças diretas de um passado não-resolvido (pré-constitucional), cujos riscos podem ser fortemente percebidos e cuja solução é uma tarefa urgente. Toda vez que há turbulência política e uma perturbação do Estado de Direito no país, o apoio à democracia parece diminuir. Nesse sentido, este artigo tem como objetivo explorar tais contradições e dificuldades e como elas ainda representam uma ameaça à democracia brasileira através de uma análise dedicada à relação complexa e ambígua que a Constituição (e várias das instituições brasileiras, como o Supremo Tribunal Federal) estabeleceu com a ditadura militar que durou de 1964 a 1985. Os fantasmas autoritários que até agora assombram a realidade brasileira, embora inevitáveis devido aos compromissos que a sustentam e às práticas que teimosamente replicam o passado no presente, precisam ao menos ser revelados e, a partir disso, desafiados por um processo de aprendizagem que apenas uma memória militante é capaz de nos tornar conscientes.

Palavras-chave: Constituição Federal do Brasil; democracia; autoritarismo; intervenção militar; ditadura.

\section{CONTENTS}

1. Introduction; 2. The Authoritarian Ghosts in Brazil and Egypt; 3. Brazilian Democratic Crisis and its Authoritarian Origin: How an Unresolved Past may Endanger Present and Future? 4. Conclusions; 5. References.

\section{INTRODUCTION}

It comes as no surprise that Brazil is facing one of its most severe political crises since 2016. Part of the literature even classify current developments as "the greatest constitutional crisis since 1988".' But its origins are no novelty to researchers that dedicate time to analyzing Brazilian constitutional history. As two of us described in a previous work, "Brazil's contemporary democratic downturn seems to be grounded in more

\footnotetext{
1 See PAIXÃO, Cristiano. 30 anos: crise e futuro da Constituição de 1988. JOTA, [s.l.], May, 3 2018. Available at: <https://www.jota.info/opiniao-e-analise/artigos/30-anos-crise-e-futuro-da-constituicao-de-198803052018>. Retrieved Jun. 5, 2018. The author understands that it is quite normal that constitutional democracies undergo periods of crises; their Constitutions have precisely the role of providing parameters within which disputes are to be fought and solved. What is extraordinary in the Brazilian political and constitutional landscapes these days is the fact that the crisis would be a de-constitutional one, which means that the 1988 Constitution is being stripped away from some of its most important parts, and such process, if not stopped, can risk the very future of the Constitution.
} 
entrenched practices that have long co-existed with its gradual process of democratization and which are now in direct clash with democracy itself." ${ }^{2}$ Under that line of thinking, our main argument in this work is that many of the ghosts that scary the Brazilian society in the Twenty-First century are direct heirs of an unresolved (pre-constitutional) past, whose risks can be strongly perceived and whose solution is an urgent task.

Even speaking of democracy is not an easy task in contemporary Brazil, because every time there is political turmoil and a disturbance to the rule of law in the country, the support for democracy seems to dwindle. ${ }^{3}$ In some occasions - such as the crisis that has struck the country and led to the impeachment of then President Dilma Rousseff -, we can observe the resurgence of calls for military intervention and the return of authoritarianism. ${ }^{4}$ At least for now, such radical moves make more fuss than pose serious risks to Brazilian democracy, though they signal that the transition from dictatorship to democracy in the country - a phenomenon deeply attached to the enactment of the 1988 Federal Constitution - has still many unresolved issues with the past. ${ }^{5}$

In this vein, this article aims to explore such contradictions and difficulties and how they still represent a threat to the Brazilian democracy through an analysis dedicated to the complex and ambiguous relation that the Constitution (and various of the Brazilian institutions, like the Supreme Court) has (have) established with the military dictatorship that lasted from 1964 until 1985. For this purpose, it will first use a diachronic comparative approach in order to demonstrate some of the ghosts that the

\footnotetext{
${ }^{2}$ BENVINDO, Juliano Zaiden; ACUNHA, Fernando José Gonçalves. Brazilian Democratic Decay and the Fear of the People, International Journal of Constitutional Law Blog, [s.l.], Jun. 24, 2017. Available at: <http:// www.iconnectblog.com/2017/06/brazilian-democratic-decay-and-the-fear-of-the-people/>. Retrieved May 30, 2018.

${ }^{3}$ According to the research group Corporación Latinobarómetro, support for democracy in Brazil reached its lowest point in 15 years in 2016, with 32\% of Brazil's respondents saying that they support democracy. It is worth remembering that 2016 was the year when the impeachment process of then President Dilma Rousseff took place. There are other interesting data: even though support for democracy increased 11 points from 2016 to 2017 (reaching 43\% of respondents), Brazilians ranked their democracy as the worst in the region in 2017 (they attributed a grade "4.2" in a scale that goes from " 1 " to " 10 ", in which the region has an average grade " 5.4 "). In 2017, Brazilians were also the group least satisfied with democracy (13\% of satisfaction), with the lowest rate of confidence in political parties (7\%), with the strongest opinion that government acts in favor of powerful groups (97\%) and with the clearest vision that government does not govern in favor of all the population (3\%). See more at: CORPORACIÓN LATINOBARÓMETRO. Informe 2017. Buenos Aires: Corporación Latinobarómetro, 2018. Available at: <http://www.latinobarometro.org/latNewsShow.jsp>. Retrieved May 31, 2018.

${ }^{4}$ Brazil is no exception to what is being observed throughout the world. In a recent interview to Brazilian newspaper Folha de S. Paulo, Professor Yascha Mounk establishes a direct connection between the lack of legitimacy of political parties and politicians in general and authoritarian alternatives. Though he does not believe that the military is close to a Coup d'État, he is concerned about the future of democracy. See at: BUARQUE, Daniel. Crise da elite política ajuda a corroer democracia, diz professor de Harvard. Folha de S. Paulo, Londres, Jun. 6, 2018. Mundo. Available at: <https://www1.folha.uol.com.br/mundo/2018/06/crise-da-elite-politica-ajuda-a-corroer-democracia-diz-professor-de-harvard.shtml?utm_source=newsletter\&utm_medium=emaiI\&utm_campaign=newsfolha $>$. Retrieved Jun. 10, 2018.
}

${ }^{5}$ See generally SKIDMORE, Thomas E. Politics in Brazil, 1930-1964: An Experiment in Democracy. New York, Oxford Univ. Press, 1967. 
1988 Constitution needs to combat in its $30^{\text {th }}$ anniversary ${ }^{6}$ if it is to be regarded as a constitutional text that fulfills its role as dispute settler. To accomplish its task, this paper will end with a brief description of the democratic crisis the country is now experiencing, drawing a connection between a past that has not been comprehensively assessed and present difficulties. The minimal ambition of this paper is to reveal that, despite the many democratic breakthroughs the transition to democracy and the drafting of a new Constitution have brought to the Brazilian reality, there is a stubborn past that has strategically done whatever it takes to keep its positions and privileges virtually untouched. Brazil has indeed changed for the better with the new democratic order and the new Constitution, but it will take many years yet to seriously challenge the various ghosts that haunts its very reality.

\section{THE AUTHORITARIAN GHOSTS IN BRAZIL AND EGYPT}

Comparative analyses are always a very risky endeavor. There are many methodological dilemmas when comparing distinct realities and even more so when those realities are marked by substantial differences in history, geography and, more specifically, political and economic developments. ${ }^{7}$ More serious, when the comparison refers to different periods in time, anachronism is not a rare outcome. ${ }^{8}$ Therefore, to use Egypt for comparison with the Brazilian constitutionalism may, at first, sound like the typical case of falling into all those methodological sins that especially historiography has pointed out as serious mistakes in research. ${ }^{9}$ Yet, even in the realm of such difficulties and in the awareness of such risks, comparative analyses may disclose interesting connections and, even when it comes to distinct times in history, a diachronic approach may reveal rich links that a synchronic one would possibly overlook. The purpose of this paper is thereby strongly diachronic by working with possible interconnections that transcend the time gap between two constitutional realities.

\footnotetext{
${ }^{6}$ As a disclaimer, it is necessary to explain that this article has some peculiarities, the most important one being the fact that it was written by three authors with distinct origins and diverse intellectual backgrounds. One of them is an Egyptian professor that lives in the country and is experiencing Brazilian everyday life (and its crises) as a foreigner coming from the Middle East. The other two are Brazilian professors that have dedicated most of their academic time to discussing and studying Brazilian and Latin American constitutionalism from the point of view of nationals that are part of such an environment. So, as a way to present a coherent argument, this article started with the observations offered by the foreigner and some of the main concerns that he was able to appoint (obviously influenced by his own background, in which risks to democracy are a permanent variable), which were then complemented by the native writers. We hope readers enjoy reading such an unusual piece of work and that it may contribute to the serious debates presented in this number.

${ }^{7}$ See HIRSCHL, Ran. Comparative Matters: The Renaissance of Comparative Constitutional Law. New York: Oxford University Press, 2014.

${ }^{8}$ See SKINNER, Quentin. Meaning and Understanding in the History of Ideas, History and Theory, [s.l.], vol. 8, n. 1, p. 3-53, 1969.

${ }^{9}$ SKINNER, Quentin. Meaning and Understanding in the History of Ideas, History and Theory, [s.I.], vol. 8, n. 1, p. 3-53, 1969.
} 
In particular for the purposes of this paper, Egypt may be a relevant paradigm for examining how the military and the authoritarian enclaves that follow suit in a dictatorship can represent a type of ghost haunting the very possibility (as in Egypt) or the consolidation (as in Brazil) of democracy. True, the very understanding of what the armed forces mean in both countries differ in many ways. Unlike in Egypt, in Brazil, though still one of the most admired institutions, ${ }^{10}$ the army is clearly under civil rule and the President, who is a civilian, is its commander-in-chief. Moreover, there is no connection whatsoever between the Brazilian army and the defense of secularism, unlike in Egypt.

These differences have to do, first, with the fact that Brazil has been a democracy for over thirty years, even though much has still to be done for it to become a full democracy; ${ }^{11}$ second, the army, especially in the aftermath of the dictatorial regime, was naturally regarded as a culprit of many of the evils of that past to overcome (the memory of that past has since faded, nonetheless, as we will discuss in more detail in part 2 of this text); and, third, notwithstanding the fact that religion plays a role in Brazilian society, the simple idea that the army has the role of defending secularism can be easily deemed a stretch to any reasonable constitutional interpretation. This is why to compare the Egypt of today, which is a military regime, with Brazil, which is a democracy ruled by a civilian government, may lead to inevitable methodological mistakes. $A$ diachronic approach seems more suitable inasmuch as it initially compares the Egypt of today with the Brazil of the years of military rule, when the army had a central role in the government, and then attempt to connect with the current Brazilian democracy. The premise here is that, in doing so, we are comparing two typical dictatorial regimes despite their different times in history, and, more especially, two regimes that have dealt with the challenges of popular protests and regime transitions in some comparable ways, though their outcomes radically differ one from the other - a very interesting point to explore, by the way.

In particular, there is an interesting comparative debate over how the military can become more democratic and whether popular mobilization helps democratize the military rule. This inquiry, in particular, expanded the spotlight in Egypt after 2011, when some citizens called for enduring protests to further revolutionary goals and

\footnotetext{
${ }^{10}$ According to a Datafolha Poll, $40 \%$ of Brazilians have a strong confidence in the armed forces and $43 \%$ have some confidence. See BILENKY, Thais. Forças Armadas lideram confiança da população; Congresso tem descrédito. Folha de S. Paulo, Jun. 24, 2017. Caderno Poder. Available at: https://www1.folha.uol.com.br/poder/2017/06/1895770-forcas-armadas-lideram-confianca-da-populacao-congresso-tem-descredito.shtml Retrieved Jun. 5, 2018. See also CORPORACIÓN LATINOBARÓMETRO. Informe 2017. Buenos Aires: Corporación Latinobarómetro, 2018. Available at: <http://www.latinobarometro.org/latNewsShow.jsp>. Retrieved May 31, 2018.

${ }^{11}$ THE ECONOMIST. The Economist Intelligence Unit's Democracy Index. [s.l.], [2018?]. Available at: <https:// infographics.economist.com/2018/Democracylndex>. Retrieved Jun. 10, 2018.
} 
others urged the opposite. Several academic studies highlighting the role of elites argued that elections could progressively corrode the political role of the armed forces and that mobilization could risk disrupting this process by provoking military backlash. ${ }^{12}$ On the other hand, it has also been argued that social forces could instead affirm that grassroots protest holds leaders accountable and pushes them toward more inclusive reform than they would otherwise enact. ${ }^{13}$

In both the current Egyptian dictatorship and the former Brazilian dictatorship, militaries took benefit of historical prestige, popular support, and institutional cohesion to seize power, and then managed the institution of elections and some civilianization of government. ${ }^{14}$ Moreover, Egypt and Brazil are geographically and demographically large and have strong ties to Western powers: they have, to a certain extent, followed relatively equivalent political economic tracks that involved industrial development, corporatist measures, and a subsequent shift to market reforms. ${ }^{15}$

Yet, various levels and sorts of popular mobilization thoroughly contributed to a variation in the speed and extensiveness of their military-controlled transitions to democracy. ${ }^{16}$ In Brazil, a military tyranny permitted elections for Congress and the other units of the federation, but might not have abandoned rule were that not recurrently demanded by numerous forms of grassroots protest. ${ }^{17}$ In Egypt, street protests toppled an autocrat (President Hosni Mubarak) and opposed totalitarian practices thereafter; however, grassroots organization after 2011 also strengthened pro-and anti-Islamist polarization and did not develop robust links to political organizations. This situation destabilized the ability of those movements to translate the troublesome power of protest into democratization and allowed the military to renew dictatorial rule. ${ }^{18}$

On the one hand, it should be noted that transitions that move too far in intimidating the interests of the military elite's risk glimmering reaction. Also, processes that do not appropriately challenge militaries can empower them to retain control in the

\footnotetext{
${ }^{12}$ See generally ACEMOGLU, Daron; ROBINSON, James. A. Economic Origins of Dictatorship and Democracy. Cambridge: Cambridge Univ. Press, 2006.

${ }^{13}$ AGÜERO, Felipe. Institutions, Transitions and Bargaining: Civilians and the Military in Shaping Post-Authoritarian Regimes. In PION-BERLIN, David; (ed.). Civil-Military Relations in Latin America: Analytical Perspectives. Chapel Hill: University of North Carolina Press, 2001, p. 194-222.

${ }^{14} \mathrm{FITCH}$, John Samuel. The Armed Forces and Democracy in Latin America. Baltimore: Johns Hopkins University Press, 1998. See also: STEPAN, Alfred. Paths towards Redemocratization: Theoretical and Comparative Considerations. In: O'DONNELL, Guillermo; SCHMITTER, Philippe C.; WHITEHEAD, Laurence. Transitions from Authoritarian Rule: Comparative perspectives, Baltimore: Johns Hopkins University Press, 1986, p. 64-84.

${ }^{15}$ DIAMOND, Larry J. Thinking about Hybrid Regimes. Journal of Democracy, vol. 13, n. 2, p. 21-35, Apr. 2002.

${ }^{16}$ See, e.g., PRZEWORSKI, Adam. Democracy and the Market: Political and Economic Reforms in Eastern Europe and Latin America. Cambridge: Cambridge University Press, 1991.

${ }^{17}$ See BARBOSA, Leonardo Augusto de Andrade. História Constitucional Brasileira: Mudança Constitucional, Autoritarismo e Democracia no Brasil Pós-1964. Brasília, Biblioteca Digital da Câmara dos Deputados, 2012, p. 149. ${ }^{18}$ See COOK, Steven A. Ruling but not Governing: The Military and Political Development in Egypt, Algeria and Turkey. Baltimore: Johns Hopkins University Press, 2007.
} 
new political system and, hence, the result might be limited or quasi-democracy, or institutionalization of a military instruction regime: a hybrid political system in which competitive elections co-exist with an army that uses formal prerogatives and/or informal relations to dictate which themes, actors, and/or policies are politically acceptable. ${ }^{19}$

Brazil's military governors directed, to a certain extent, a gradual liberalization of the political system, though, during the Constituent Assembly of 1987/1988, their capacity to do so was, in many respects, effectively challenged by important sectors of organized civil society. ${ }^{20}$ Three years after the inauguration of Brazil's first civilian president since 1964, the military elites and conservative sectors of the Brazilian society could still retain control over much of the political atmosphere they had occupied during the twenty-one years of military rule. ${ }^{21}$ This reality would nonetheless be in clash with a rising participation of distinct sectors of society and would create an environment of constitution-drafting in 1987 and 1988 where compromises with the past and democratic breakthroughs would appear side by side. ${ }^{22}$

This clash is the result of the socioeconomic alterations that gave rise to new civil society groups, such independent labor unions that were gaining strength especially since the seventies. ${ }^{23}$ Additionally, a rising middle class shaped professional associations that gradually opposed tyranny and, as urban growth outstripped public services, poor residents organized to meet essential needs, forging networks that would later be used to channel protest. ${ }^{24}$ Further, both liberation theology and government repressiveness pushed the Catholic Church to condemn human rights violations and demand

${ }^{19}$ PRZEWORSKI, Adam. Democracy and the Market: Political and Economic Reforms in Eastern Europe and Latin America. Cambridge: Cambridge University Press, 1991, p. 72-79.

${ }^{20}$ See BENVINDO, Juliano Zaiden, The Forgotten People in Brazilian Constitutionalism: Revisiting Behavior Strategic Analyses of Regime Transitions. International Journal of Constitutional Law, vol. 15, issue 2, p. 332-357, Apr. 2017, at p. 332.

${ }^{21}$ See BENVINDO, Juliano Zaiden, The Forgotten People in Brazilian Constitutionalism: Revisiting Behavior Strategic Analyses of Regime Transitions. International Journal of Constitutional Law, vol. 15, issue 2, p. 332-357, Apr. 2017, at p. 340 et seq. See also: "The basis of this expectation lay in the strength of the military government's bargaining position vis-à-vis civilians during the transition to civilian rule, which resulted in the armed forces' retention of institutional prerogatives, including six cabinet positions and a predominant presence in the National Security Council (CSN) and National Information Service (SNI), agencies synonymous with the abuse of human rights under the dictatorship. It was predicted that these prerogatives would provide the military with a strong foundation for exercising tutelage over civilians and protecting the privileges of their institution in the new democracy" (HUNTER, Wendy. Politicians Against Soldiers: Brazil. Comparative Politics, vol. 27, n. 4, p. 425-443, Jul. 1995, at p. 425).

${ }_{22}$ Popular mobilization was critical in derailing that outcome, as several expansions permitted that mobilization. Wendy Hunter adds to that electoral competition and financial causes. See: HUNTER, Wendy. Politicians Against Soldiers: Brazil. Comparative Politics, vol. 27, n. 4, p. 425-443, Jul. 1995, at p. 439-440.

${ }^{23}$ By 1978 , it has been reported that some $43 \%$ of workers have been included. See FAUSTO, Boris. A Concise History of Brazil. Cambridge: Cambridge University Press, 1999, at p. 304.

${ }^{24}$ AVRITZER, Leonardo. Civil Society in Brazil: From State Autonomy to Political Interdependency. Belo Horizonte, [s.n.], 2009, at p. 10. See also AVRITZER, Leonardo. Participatory Institutions in Democratic Brazil. Washington: Wilson Press Johns Hopkins, 2009. Changes in the agrarian economy and farming brought small producers and rural and blue-color workers together in new sorts of collective action and representation. See 
for social justice. ${ }^{25}$ By providing a "protective umbrella" for the poor, Church-fostered local clerical communities endorsed participatory standards and political criticism. ${ }^{26}$ The open dialogue policy adopted with the civil society in 1974, for example, restored habeas corpus and press freedoms.

Accordingly, protest movements created both popular insistence on democracy and tools for articulating its mobilization. The military government in Brazil, though largely constraining political parties to only two big coalitions - MDB and ARENA - after the enactment of the Institutional Act no. 2 in 1965, ${ }^{27}$ allowed some party competition in Congress and in state and municipal legislatures ${ }^{28}$ (this two-coalition system would last until 1979). In this respect, the military expanded elections as it thought that it could dictate outcomes, as it had assets, including a relatively economic success and some public support, with which it could arrange the transition while protecting its privileges. ${ }^{29}$ Others contended that democratization flourished due to the military's internal divisions, as they asserted that a reasonable faction never proposed to hold power. ${ }^{30}$ In any event, the military soft-liners would not have succeeded in corroding dictatorship without the influence produced by a mobilized civilian opposition. ${ }^{31}$

Egypt's 2011 uprising brought varied social sectors together to demand freedom, dignity, and social justice. The military, distinguishing itself from the police in declining to shoot protestors, arisen heroically when it forced the long 30 years ironfist autocratic leader, President Hosni Mubarak, to resign and the Supreme Council of Armed Forces (SCAF) assumed power. ${ }^{32}$ Many scholars recommended that Egypt follow

NAVARRO, Zander. Democracy, Citizenship and Representation: Rural Social Movements in Southern Brazil 1978-1990. Bulletin of Latin American Research, vol. 13, n. 2, p 129-154, May 1994.

${ }^{25}$ MAINWARING, Scott. Urban Popular Movements, Identity, and Democratization in Brazil. Comparative Political Studies, vol. 20, issue 2, p. 131-159, July 1987, at p. 146-155. Available at: <https://doi.org/10.1177/00104 $14087020002001>$. Retrieved Jun. 5, 2018.

${ }^{26}$ MAINWARING, Scott. Grass Roots Popular Movements and the Struggle for Democracy: Nova Iguaçu, 19741985. In: STEPAN, Alfred (ed.) Democratizing Brazil. New York: Oxford University Press, 1989, pp. 168-204.

${ }^{27}$ BRAZIL. Ato Institucional n. 2, of October, 27, 1965. Mantem a Constituição Federal de 1946, as Constituições Estaduais e respectivas Emendas, com as alterações introduzidas pelo Poder Constituinte originário da Revolução de 31.03.1964, e dá outras providências. Diário Oficial da União, Brasília, DF, Oct. 27, 1965. Available at: <http://www.planalto.gov.br/ccivil_03/ait/ait-02-65.htm>. Retrieved Jun. 5, 2018.

${ }^{28}$ MAINWARING, Scott. Grass Roots Popular Movements and the Struggle for Democracy: Nova Iguaçu, 19741985. In: STEPAN, Alfred (ed.) Democratizing Brazil. New York: Oxford University Press, 1989, pp. 168-204.

${ }^{29}$ STEPAN, Alfred. Paths towards Redemocratization: Theoretical and Comparative Considerations. In: O'DONNELL, Guillermo; SCHMITTER, Philippe C.; WHITEHEAD, Laurence. Transitions from Authoritarian Rule: Comparative perspectives, Baltimore: Johns Hopkins University Press, 1986, p. 64-84, at p. 59-60.

${ }^{30}$ SKIDMORE, Thomas E. Brazil: Five Centuries of Change. 2 ed. New York: Oxford University Press, 2009.

${ }^{31}$ SKIDMORE, Thomas E. Brazil: Five Centuries of Change. 2 ed. New York: Oxford University Press, 2009, at p. 184. Only after the rise of the labor movement was the more limited process of liberalization transformed into democratization.

32 'ARAFA, Mohamed A. Towards a Culture of Accountability: A New Dawn for Egypt. Phoenix International Law Review, vol. 5, issue 1, p. 1-39, 2011, at p. 12-15. See ABDEL-MALEK, Anouar. Egypt: Société Militaire. Paris: Editions de Seuil, 1962, at p. 330. 
a "Turkish model" toward democracy. The two groups in Egypt to which Turkey offered a model were the military and the Muslim Brotherhood (MB). ${ }^{33}$ To the former, it exposed paths to shape the political arena to defend its main benefits and, to the latter, it verified how a populist Islamist party could be elected and deteriorate the military reserve domains, while relegating political rivals. ${ }^{34}$ It should be noted that the Egyptian military enjoyed huge institutional cohesion, social respect (prestige), and a historic leadership role, as its power stemmed from a budget exempted from oversight, close ties to the United States and the European Union countries, especially within the counterterrorism programs and fighting Islamic extremists, Suez Canal as a global water passageway and guaranteeing stability with Israel, along with an economic empire in such industries - as tourism, construction, and industrial manufacturing - and networks within bureaucracy and local administration. ${ }^{35}$

While revolutionary groups promoted postponing elections until they could build organized political parties, the military rapidly held elections in 2012 to transfer power to its favored interlocutors - the Muslim Brotherhood, to be easy for them afterwards to remove them, as it happened -, traditional parties and local power dealers. ${ }^{36}$ While declining calls to renovate the security apparatus, the military required the

\footnotetext{
${ }^{33}$ 'ARAFA, Mohamed A. Towards a Culture of Accountability: A New Dawn for Egypt. Phoenix Law Review, vol. 5, issue 1, p. 1-39, 2011.

${ }^{34}$ 'ARAFA, Mohamed A. Towards a Culture of Accountability: A New Dawn for Egypt. Phoenix Law Review, vol. 5, issue 1, p. 1-39, 2011. See also: ("After 1991, the Egyptian Armed Forces expanded their thorough penetration of almost every sphere of Hosni Mubarak's crony patronage system. The senior officer corps was co-opted by the promise of appointment upon retirement to leading posts in government ministries, agencies, and state-owned companies, offering them supplementary salaries and lucrative opportunities for extra income generation and asset accumulation in return for loyalty to the president. This officers' republic served as a primary instrument of presidential power, and even after Mubarak's ouster retains its pervasive political reach, permeating both the state apparatus and the economy - not just at the commanding heights but at all levels." (SAYIGH, Yezid. Above the State: The Officer's Republic in Egypt. Carnegie Middle East Center, Aug. 1, 2012. Available at: <http://carnegie-mec.org/2012/08/01/above-state-officers-republic-in-egypt-pub-48972>. Retrieved Jun. 7, 2018.).

${ }^{35}$ See COOK, Steven A. Ruling but not Governing: The Military and Political Development in Egypt, Algeria and Turkey. Baltimore: Johns Hopkins University Press, 2007. See also AMAR, Paul. Why Mubarak is Out. In: HADDAD, Bassam; BSHEER, Rosie; ABU-RISH, Ziad (ed.). The Dawn of the Arab Uprisings: End of an Old Order? London: Pluto Press, 2012, p. 83-90, at p. 81-85.

${ }^{36}$ "When he took office on June 30, President Muhammad Mursi of Egypt looked to have been handed a poisoned chalice. The ruling generals (...) had tolerated a clean presidential election but then had hollowed out the presidency, saddling Mursi with an executive's accountability but little of the corresponding authority. The country resigned itself to the grim reality of dual government, with an elected civilian underdog toiling in the shadow of mighty military overlords. Then, (...) Mursi turned the tables, dismissing Egypt's top generals and taking back the powers they had usurped. The power play crystallizes the new dynamic of Egyptian politics: the onset of open contestation for the Egyptian state. For 60 years, an exclusive military-bureaucratic caste ran the state, beating back ambitious counter-elites, Islamist or otherwise. Politics became a scramble for small advantages, gained by petitioning the state, seeking its largesse or striving for representation in an ornamental legislature." (EL-GHOBASHY, Mona. Egyptian Politics Upended. Middle East Research and Information Project, 20 Aug. 2012, Available at: <https://www.merip.org/mero/mero082012>. Accessed: 7 Jun. 2018).
} 
institutionalization of reserve spheres in anticipation that its informal impact might reduce after elections. ${ }^{37}$

Protest remains part of this political landscape and major protests - until the moment - have condemned military rule and demanded accountability for misuses. Generally, popular mobilization's input to democratization remain limited - and will keep as that - if mobilization does not bridge cleavages or develop or create robust political organization. In terms of how mobilization's features weakened its democratizing influence, protest movement in Egypt had a restricted impact in creating popular demand for democratization. The military turned public opinion against protestors before demonstrators could turn public opinion against them, as the army usurped the legitimacy of the political (youth activism) movement by suggesting - in the name of the revolution - that protest represented threatening, excessive democratization. ${ }^{38}$ Meanwhile, the military used violent and legal repression to stop protest and drag protestors into bloody clashes, as they denounced activism as gangsters, convincing numerous Egyptians that demonstrators were ruining the economy demonstrating for the sake of protesting. ${ }^{39}$

Additionally, popular mobilization did not upsurge politicians' enticements to confront military power-holders, and the grassroots protest did not change this policy. ${ }^{40}$ Further, popular mobilization had a diverse impact on politicians' capacities for stimulating military rule, as, for example, the massive protests, pressuring the military to announce presidential elections and affirm that it had no aspirations to govern (chanting "Down with the Military Rule") after Mubarak's ouster. ${ }^{41}$ Popular mobilization

\footnotetext{
${ }^{37}$ See generally KANDIL, Hazem. Soldiers, Spies, and Statesmen: Egypt's Road to Revolt. London:Verso, 2014.

${ }^{38}$ SAYIGH, Yezid. Above the State: The Officer's Republic in Egypt. Carnegie Middle East Center, Aug. 1, 2012. Available at: <http://carnegie-mec.org/2012/08/01/above-state-officers-republic-in-egypt-pub-48972>. Retrieved Jun. 7, 2018.

${ }^{39}$ Without managerial leadership and strong association and unification, activists were not able to communicate or pass their own message convincingly, no less rally the population to reject military government. See: "Agreeing with Abdel-Gawad, prominent lawyer Ragaie Attia said: 'The irresponsibility of these revolutionary youth movements led the vast majority of citizens to seek shelter in a man with a strong personality and who can stand up to these anarchistic elements and contain Islamists.'" (EL-DIN, Gamal Essam. How Did Muharak's Last PM Make it to Egypt's Second Round of Presidential Elections? Jadaliyya, May 26, 2012. Available at: <http://www.jadaliyya.com/Details/26064/How-Did-Mubarak\%60s-Last-PM-Make-It-To-Egypt\%60s-SecondRound-of-Presidential-Elections $>$. Retrieved Jun. 7, 2018).

${ }^{40}$ In this regard, the MB intended that if it played by the military's rules, it could move to attain political power. See, e.g.: "Indeed, as a highly institutionalized, hierarchical organization, the Brotherhood has always prioritized structures over individuals. It is telling that, in recent decades, the Brotherhood has failed to produce any charismatic leaders on the national level. So, when it comes to Egyptian politics, the Brothers are also institutionalists." (HAMID, Shadi. The Muslim Brotherhood's New Power in Egypt's Parliament. Brookings, Dec. 23, 2011, Available at: <https://www.brookings.edu/opinions/the-muslim-brotherhoods-new-power-in-egyptsparliament/>. Retrieved Jun. 5, 2018).

${ }^{41}$ "A large showing of Egypt's political forces took to Egypt's revolutionary square for the 'Friday of One Demand,' seeking a swift transfer of power and refusing the government's supra-constitutional principles. (...) Hundreds of thousands of protesters descended on Tahrir Square (...) to call for one principal demand: an
} 
was associated with a political organization, which facilitated it to translate street power into targeted influence in bargaining with military elites. However, its influence in deepening democratization was restricted because it reinforced rather than spanned crucial cleavages. ${ }^{42}$ Finally, the effect of mobilization in thwarting dictatorship after the election of a civilian government saw a similarly mixed record. ${ }^{43}$ Subsequently, demonstrators along with activists accused the MB of ineffectiveness, economic failure, and an exclusionary effort to colonize institutions and disregard opposition voices. ${ }^{44}$

A grassroots petition campaign (tamrod) collected signatures against Morsi and, on June 30, 2013, united millions of Egyptians again to the streets to demand his resignation; this mobilization sustained until July 3, when the military removed the government, arrested Morsi, and suspended the constitution. ${ }^{45}$ Islamist supporters shaped a protest camp that ended with military and security bloody clashes, then banned the MB and labeled it as terrorist organization by a court's decision, arrested tens of thousands on trumped-up charges, and severely restricted freedom of expression and speech. Finally, the Commander-in-Chief (former defense minister) 'Abdel Fattah el-Sisi won presidential elections in May 2014 and March 2018 nearly unopposed. ${ }^{46}$

The current military government has been surpassed by a wave of arrests that has swept up numerous of the country's remaining independent civilians and reporters (bloggers and activists) who have been calling attention to police brutality, massive economic corruption and fraud, lack of judicial independence, rule of law, and other human rights violations. ${ }^{47}$ Detainees have been charged with aiding a terrorist

end to military rule and a swift transfer of power to an elected president by April 2012." (TAREK, Sherif. Egypt's Islamists Dominate Tahrir Square's Dense Friday. Ahram Online, Nov. 18, 2011. Available at: <http://english. ahram.org.eg/NewsContent/1/64/26902/Egypt/Politics-/Egypts-Islamists-dominate-Tahrir-Squares-dense-Fri. aspx>. Retrieved Jun. 8, 2018. See also EL-HAMALAWY, Hossam. Morsi, SCAF, and the Revolutionary Left. Jadaliyya, Jul. 1, 2012. Available at: <http://www.jadaliyya.com/Details/26430/Morsi,-SCAF,-and-the-RevolutionaryLeft>. Retrieved Jun. 7, 2018.

${ }^{42}$ KANDIL, Hazem. Soldiers, Spies, and Statesmen: Egypt's Road to Revolt. London: Verso, 2014, at p. 246.

${ }^{43}$ Moreover, the MB's relationship to the military endured. Uncertain Morsi ordered the retirement of senior commanders, but he did not take more meaningful steps to assert civilian control over the military or investigate their violence. At that time, Morsi granted himself comprehensive extrajudicial powers, above the law, surging protests forced him to repeal the decree (rule by man not rule of law).

${ }^{44}$ See generally 'ARAFA, Mohamed A. Whither Egypt? Against Religious Fascism and Legal Authoritarianism: Pure Revolution, Popular Coup, or a Military Coup D'État? Indiana International \& Comparative Law Review, vol. 24, n. 4, p. 859-897, 2014.

${ }^{45}$ 'ARAFA, Mohamed A. Whither Egypt? Against Religious Fascism and Legal Authoritarianism: Pure Revolution, Popular Coup, or a Military Coup D'État? Indiana International \& Comparative Law Review, vol. 24, n. 4, p. 859-897, 2014.

${ }^{46}$ See 'ARAFA, Mohamed A. The Unexpected Trials of Egyptian Leaders: Is It a Question of Law or Politics? US China Law Review, vol. 12, n. 6, p. 467-487, 2015. Though there was some hope that Sisi might ease what has been the worst suppression and tyranny in Egypt's modern history, he recently awarded himself another mandate with a bizarrely rigged presidential election.

${ }^{47}$ For example, Egypt's military government issued what become known as the "protest law," effectively outlawing freedom of assembly and demonstration. See: "Egypt now finds itself ruled by a military, security and 
organizations and "spreading false news." The military-backed government justifies it as if it were fighting Islamist extremists connected to the terrorist Islamic State, but most of those recently arrested are well-known secular liberals who supported Egypt's 2011 pro-democracy movement. ${ }^{48}$

Egypt's transition may illustrate some comparable elements from the Brazilian experience, though the outcomes differ radically: one brought, in the end, the military into power; the other led to a democracy ruled by a civilian government. In Egypt, some argue that popular mobilization gave the military an excuse to seize power and led numerous citizens, tired and exhausted with instability and insecurity, to praise the army's rule and justify extensive human rights transgressions. ${ }^{49}$ Yet renewed totalitarianism in Egypt may also have to do to the failure of mobilization to build robust organizational linkages between grassroots movements and political leaders, which opened up the space for interest groups to foster their interests in the aftermath of the transition. It seems that even after uprisings in Egypt, there appeared to be no organized actor capable of establishing democracy and challenging the military's political supremacy, oppressive performs, or propaganda. That doesn't mean that crackdown has no cost: history, after all, proposes that regimes as such stores up trouble that, in the end, will be uncontainable and irrepressible.

A diachronic approach reveals that the gap between both comparative paradigms may lie in the fact that, even though also in Brazil the capacity of fostering linkages between grassroots movements and political leaders is relatively scant, it is not absent, either. In reality, those protests of the seventies which resulted in a greater popular participation during the Constituent Assembly of 1987/1988 have not only provided a more inclusive procedure of constitution-making, but also a symbolic legitimation of that very procedure. It strengthened a transition that was originally aimed to be (totally) controlled, but which gained another configuration within the works of that Constituent Assembly. In other words, in Brazil sectors of organized civil society were successful, though with some constraints by opposition and conservative groups, in channeling their agendas into the political arena and into a constitutional moment,

intelligence junta. Egypt's generals have constantly employed repressive tools to instill fear among the population in order to stifle free expression and peaceful opposition. The military clique's goal here is to evacuate citizens from the public space, to eliminate the autonomy of civil society organizations and to marginalize political parties that are not controlled by the security and intelligence services." (HAMZAWY, Amr. Egypt's Anti-Protest Law: Legalizing Authoritarianism. Al-Jazeera, Nov. 24, 2016. Available at: <https://www.aljazeera. com/indepth/features/2016/11/egypt-anti-protest-law-legalising-authoritarianism-161107095415334.html>. Retrieved Jun. 5, 2018).

${ }^{48}$ In the actual war against extremists on the Sinai Peninsula, the government is deteriorating and failing despite the use of cruel strategies.

${ }^{49}$ See EDITORIAL BOARD. Acting Out of Weakness, Sissi Launches Another Crackdown, Washington Post, The Post's View, June 1, 2018. Available at: <https://www.washingtonpost.com/opinions/global-opinions/ egypt-is-being-run-by-a-jailer/2018/06/01/fa436c0c-64f5-11e8-99d2-0d678ec08c2f_story.html?utm_ter$\mathrm{m}=.0 \mathrm{~b} 037 \mathrm{f} 4 \mathrm{bb} 5 f 9>$. Retrieved Jun. 5, 2018. 
and this has positively played out to gradually strengthen democracy. In the following years, the rise especially of the Worker's Party (PT) and other left-leaning political parties, which were very influential and active before and during the Constituent Assembly, signaled this linkage with some of those grassroots movements and it is no wonder that, for thirteen years, it ruled the country with some policies aimed at including some disadvantaged groups in Brazil, though being able to do so by compromising with some society's traditional sectors.

Naturally, unlike in Egypt, the military represented the regime that was going downhill and, as such, could not claim the role of saviors against trumped-up enemies anymore (as they did when they took power in 1964). Rather, they were still influential actors of the transition who would need to negotiate their positions in other terms. Some authoritarian enclaves - the ghosts of the dictatorship - remained strong both in the law and in practice ${ }^{50}$ as the outcome of constitutional compromises and the very context of years of dictatorship and the social disparities that have long been a feature of the Brazilian society, but no one can deny that that was a democratic moment that resulted in a constitutional moment.

Yet history proves itself more troubled, and democratic and constitutional moments are themselves an achievement that is fragile if not properly cared and if history does not become a memory to be always remembered. Those authoritarian legacies will, by the same token, do whatever it takes to regain their influence and rebuild their agendas, especially by strategically using the very constitution, its mechanisms and other strategies to unsettle constitutionalism. ${ }^{51}$ By the same token, it will take advantage of any crisis, either political or economic, to reaffirm its quality of caretaker government to gradually lay the groundwork for reassuring the strength of its positions in the definition of the future. The events that took place after the transition to democracy in Brazil are evident examples of these movements that, while seeming to be heading forward, are commonly pushed backwards whenever they challenge that past. The question is, therefore, how they can effectively endanger that future.

\section{BRAZILIAN DEMOCRATIC CRISIS AND ITS AUTHORITARIAN ORIGIN: HOW AN UNRESOLVED PAST MAY ENDANGER PRE- SENT AND FUTURE?}

Politics and policy-making in Brazil have long been marked by diverse symptoms of democratic malfunction. Inequality (material, economic, and political), powerlessness of most parts of the population, widespread disenfranchisement, and a steep

\footnotetext{
${ }^{50}$ See next section.

${ }^{51}$ LANDAU, David. Abusive Constitutionalism. University of California-Davis Law Review, vol. 47, p. 189-260, 2013.
} 
gap between those who are to be represented ("The People") and their representatives are common features of Brazilian institutions even post-dictatorship, despite one of the most progressive and democratic Constitutions of the world. As two of us stated elsewhere, "the Brazilian political system (...) is being challenged because of its inability to dialogue with civil society", because it operates in a context in which "Brazilian institutions, in general, and the political class, in particular, have adapted themselves to make use of some antidemocratic practices that subvert the very idea of political representation", a reality that led us to conclude that "Brazilian democratic institutions (...) are still very fearful of the people they should represent." ${ }^{\prime 2}$

In this vein, lack of representativeness, illegitimacy, widespread disillusionment with the political class and political parties, economic turmoil, and an enduring and all-encompassing inequality make up a complex landscape within which democracy needs to operate in Brazil. Moreover, there are some new aspects to consider: the Brazilian political spectrum has been permanently agitated by calls to return to the past. That is the reason why the political scenario cannot be adequately understood if another component of Brazilian constitutional system is left behind. We are talking about the way the 1988 Federal Constitution (and the organs whose task is to enforce it, e.g. the Federal Supreme Court) deals with the country's authoritarian past.

As we said, Brazilian political life is witnessing a renewed desire for military rule. A desire to return to an age when politics was strictly controlled in a bipartisan system in which the government almost always had the majority in Congress, when Brazilians did not vote for President for more than 25 years, and when thousands of opponents were haunted, imprisoned, killed or forced to flee the country. Within social media tools, from Facebook and Twitter to radio's talk, and even in street demonstrations (small but innumerous), nostalgia for dictatorship and repression - and worry about the "democratic excesses" - have found a very powerful channel for their grievances. Many put their hopes in speeches of politicians such as Jair Bolsonaro (the far-right candidate who is one of the frontrunners in the next presidential elections ${ }^{53}$ ) and others of his kind.

\footnotetext{
${ }^{52}$ BENVINDO, Juliano Zaiden; ACUNHA, Fernando José Gonçalves. Brazilian Democratic Decay and the Fear of the People, International Journal of Constitutional Law Blog, [s.l.], Jun. 24, 2017. Available at: <http:// www.iconnectblog.com/2017/06/brazilian-democratic-decay-and-the-fear-of-the-people/>. Retrieved May 30, 2018.

${ }^{53}$ See: "Bolsonaro insists that, like Trump, he will lean on his strong social media following to get out his message to the millions of Brazilians fed up with spiraling violence, pervasive corruption and unwanted immigration. "I'm a threat to oligarchies, I'm a threat to the stubbornly corrupt, I'm a threat to those who want to destroy family values," he said. "That's the threat I represent." Brazil's middle classes have watched their status dwindle along with their income as the economy shrank almost 8 percent over the past two years, allowing Bolsonaro to tap a rich seam of anger and frustration. Budget cuts have weakened precarious public services and the country's unfathomable levels of violence have continued to rise, strengthening the appeal of his hard-line security policies. Amid the almost daily revelations of egregious corruption by the country's political elite, Bolsonaro's unblemished record on graft has only added to his appeal among a disenchanted electorate." (BILLER, David; DOUGLAS, Bruce. The Donald Trump of Brazil' Soars in the Polls. Bloomberg, Oct. 13, 2017. Politics.
} 
Open languages and tones of homophobia, sexism, bigotry, and racism have become more pronounced ${ }^{54}$ as part of a relentless war against "political correctness." Furthermore, there is a growing belief that democratic institutions are flawed, the courts are partial and used as political instruments, ${ }^{55}$ and political parties are consistently weak and corrupt ${ }^{56}$ (as generally well-known, political corruption is a real fact of public life in Brazil). It is no wonder that, since the country's transition to democracy, corruption has been: 1) "a challenge for each presidential administration,"57, 2) the modus operandi of the fragmentary political system, and, to a certain extent, a reality also in the Brazilian judiciary. ${ }^{58}$

All of this feeds up calls for a new period of military rule (or "military intervention", as some demonstrators and enthusiasts insist to name it based on an evidently unconstitutional interpretation of Article 142 of the Constitution ${ }^{59}$ ). And we believe history has much to say here, because there is strong evidence in favor of a direct link between the way the new democratic regime inaugurated in 1988 dealt with its pre-constitutional past (or did not do so) and how such a past is being recast. Stating simply: The Constitution did not address the authoritarian period in a way it should have done; therefore, it left the door open for such an "authoritarian ghost," and the time to solve the question is now.

Available at: <https://www.bloomberg.com/news/articles/2017-10-13/ex-army-captain-rises-in-brazil-pollsas-threat-to-the-corrupt>. Retrieved June 9, 2018).

${ }^{54}$ See BARROSO, Luís Roberto; BENVINDO, Juliano Zaiden; OSÓRIO, Aline. Developments in Brazilian Constitutional Law: The Year 2016 in Review. International Journal of Constitutional Law, vol. 15, n. 2, p. 495-505, June 30, 2017. Available at: <https://doi.org/10.1093/icon/mox038>. Retrieved Jun. 11, 2018.

${ }^{55}$ Empirically, though, the Brazilian judicial system has been regarded as one of the most independent in Latin America. See HELMKE, Gretchen; RIOS-FIGUEROA, Julio. Courts in Latin America. Cambridge: Cambridge University Press, 2011, p. 19.

${ }^{56}$ HELMKE, Gretchen; RIOS-FIGUEROA, Julio. Courts in Latin America. Cambridge: Cambridge University Press, 2011, p. 19.

${ }^{57}$ POWER, Timothy J.; TAYLOR, Matthew M. Accountability Institutions and Political Corruption in Brazil. In POWER, Timothy J.; TAYLOR, Matthew M. (ed.) Corruption and Democracy in Brazil: The Struggle for Accountability. Notre Dame: University of Notre Dame Press 2011, p. 1.

${ }^{58}$ ALBERT, Richard; BENVINDO, Juliano Zaiden; RADO, Klodian; ZHILLA, Fabian. Constitutional Reform in Brazil: Lessons from Albania? Revista de Investigações Constitucionais, vol. 4, n. 3, p. 11-34, set./dez. 2017.

${ }^{59}$ Which declares: "The Armed Forces, made up of the Navy, Army and Air Force, are permanent and regular national institutions, organized on the basis of hierarchy and discipline, under the supreme authority of the President of the Republic, and intended to defend the Nation, guarantee the constitutional branches of government and, on the initiative of any of these branches, law and order." See BRAZIL. Constituição da República Federativa do Brasil, of October 5, 1988. Diário Oficial da União, Brasília, DF, Oct. 5, 1988. Available at: <http:// www.planalto.gov.br/ccivil_03/constituicao/constituicao.htm>. Retrieved Jun. 12, 2018. "Interventionists" see an opening to military action based on the assumption that Article 142 disciplines the guarantee of "law and order". Since there is a "danger" to "law and order" stemming from the ongoing crisis, military leaders would be entitled to act, so the argument goes. We understand that it is a misperception, to say it softly, because a (not so difficult) textual interpretation of Article 142 reveals that the President of the Republic is the commander-in-chief of the Armed Forces, whose "intervention" is only possible upon a direct call from one of the branches of the government. 
But what do we mean when we say that "the Constitution did not address the authoritarian period in a way it should have done" and what are the stakes? In terms of democratic transition, it is widely known that Latin America implemented in recent decades significant mechanisms of transitional justice that have contributed to the realization of human rights. ${ }^{60}$ As a way of addressing the legacy of past violence and consolidation of democracy, the region is indicating, to some degree, its ability to deal with these specific problems. ${ }^{61}$

Brazil, however, lags behind some other countries in the region that have also endured dictatorships - like Chile, Uruguay, and Argentina -, where not only truth commissions have been created (as is the case of Brazil ${ }^{62}$ ), but also the review or repeal of amnesty laws laid down by military governments has led to the conviction of perpetrators of heinous crimes during those dictatorships. Here, an authoritarian past continues to scary democracy and is about to take its toll unless it is properly exorcised.

The Brazilian Constitution of 1988 chose a peculiar path. It is undeniable that it has devoted its core to the protection of human rights as fundamental rights (which are expressly deemed as unamendable clauses ${ }^{63}$ ). Besides that, throughout its provisions, it is easily perceived that it has also dedicated itself to protecting labor relations, to establishing a democratic system with checks and balances, to promoting health, education and other social, economic and cultural rights, to recognizing rights of indigenous populations, to eliminating gender inequality, and so forth. All of it was only possible because the society as a whole struggled to overcome more than 20 years of an authoritarian and repressive regime, a process that reached its climax precisely with the enactment of the very 1988 Constitution.

But it did not happen without resistance and eventual shortcomings. More than that, it only happened with compromises and the adoption of a mixed formula. It is worth remembering that the regime that lasted from 1964 to 1985 profited from a

\footnotetext{
${ }^{60}$ BUNCE, Valerie. Comparative Democratization: Big and Bounded Generalizations. Comparative Political Studies, vol. 33, issue 6-7, p. 703-734, 2000.

${ }^{61}$ As a matter of fact, it is an undisputable success of the whole region to democratize itself, though it is equally undeniable the exclusivity of each situation in national processes. It does not mean this is a process free of critics. But this initial recognition is vital, for example, to understand the ways of transitional justice in South America, as in Brazil, and recently in the Arab Word, as in Tunisia and Egypt.

${ }^{62}$ In the same vein, Argentina is charging the perpetrators of crimes committed during the military regime; Chile is recognizing the right to effective politics of memory through, e.g. the construction of memorials; Colombia is investigating paramilitaries and guerrillas as part of the process of peace and justice; Peru is implementing collective reparations programs; and Guatemala is seeking to compensate their victims, just to name a few.

${ }^{63}$ See the 1988 Brazilian Constitution, art. $60, \S 4^{\text {th }}$, IV (BRAZIL. Constituição da República Federativa do Brasil, of October 5, 1988. Diário Oficial da União, Brasília, DF, Oct. 5, 1988. Available at: <http://www.planalto.gov.br/ ccivil_03/constituicao/constituicao.htm>. Retrieved Jun. 12, 2018).
} 
strong support from society in most of its years. ${ }^{64}$ The influence of groups that had enjoyed power during the military dictatorship was a force within the Constituent Assembly, as was the increasing participation of the organized civil society during the works of the same Assembly in 1987/1988. ${ }^{65}$ As Andrei Koerner explains through the concept of "long Constituent Assembly", the new Constitution was initially a "transitory commitment" between opposing political forces present in the constituent works, ${ }^{66}$ and the interpretation and the enforcement of the new Constitution was disputed from the very beginning. Privileged groups fought arduously to keep their positions in the new era, as it is the case of the members of the Federal Supreme Court and the Judiciary in general. ${ }^{67}$ As they managed (at least partially) to maintain some of their privileges and powers, the author stresses that the progressive potential of the new Constitution was partly doomed. It was also the case of the military, whose influence is still present in the Brazilian constitutional democracy (though naturally reduced compared to the older constitutional order $^{68}$ ). It is still visible in some spheres, e.g. the military nature of the police, ${ }^{69}$ the maintenance and continued enforcement of the Amnesty Law, ${ }^{70}$ among others.

\footnotetext{
${ }^{64}$ See CARVALHO, Alessandra. As Atividades Político-Partidárias e a Produção de Consentimento durante o Regime Militar Brasileiro. In: ROLLEMBERG, Denise; QUADRAT, Samantha V. (org.). A Construção Social dos Regimes Autoritários: Legitimidade, Consenso e Consentimento no Século XX - Brasil e América Latina. Rio de Janeiro: Civilização Brasileira, 2011, p. 219-250

${ }^{65}$ BENVINDO, Juliano Zaiden. The Forgotten People in Brazilian Constitutionalism: Revisiting Behavior Strategic Analyses of Regime Transitions, International Journal of Constitutional Law, vol. 15, issue 2, p. 332-357, Apr. 2017.
}

${ }^{66} \mathrm{KOERNER}$, Andrei. Os tempos da ordem constitucional - controle da constitucionalidade e continuidade legal na transição democrática no Brasil. In: SEMINÁRIO INTERNACIONAL "OS TEMPOS DO DIREITO: DIACRONIAS, CRISE, HISTORICIDADE", Brasília, 2016, p. 1-12.

${ }^{67} \mathrm{~A}$ paradox is evident: as the members of the Supreme Court managed to remain in office and preserved their powers (including the power to dictate the last word in constitutional matters), the new democratic Constitution would be mainly interpreted and enforced by agents coming from the authoritarian past. Such an outcome provoked enormous effects to a reasonable part of the Constitution, whose transformative potential was contained and repressed. For more details, see BENVINDO, Juliano Zaiden; ACUNHA, Fernando José Gonçalves. Tempos na atuação da jurisdição constitucional: A interpretação inicial do STF a respeito do Mandado de Injunção e as oportunidades que não voltam In: PAIXÃO, Cristiano; MARTINS, Argemiro Cardoso Moreira (org.). Os tempos do direito: diacronias, crise, historicidade. São Paulo, Max Limonad, 2019 (forthcoming).

${ }^{68}$ As Wendy Hunter writes, "Also, Brazilian politicians have not yet subjected the armed forces to institutionalized civilian control, an undertaking that would go well beyond contesting their influence over specific issues. While all politicians have a long-term interest in keeping the military at bay, individuals (especially legislators) are often reluctant to expend the political capital necessary to institute and sustain systematic civilian control" (HUNTER, Wendy. Politicians Against Soldiers: Brazil. Comparative Politics, vol. 27, n. 4, p. 425-443, jul. 1995, at p. 440).

${ }^{69}$ According to Maria Pia Guerra, the creation of a military police in every Brazilian state along with the militarization of various of its activities - like street patrolling -, was undertaken by the military government as a result of the National Security ideology. The 1988 Constitution maintained this model and crystalized this military component in everyday life of Brazilian society. See GUERRA, Maria Pia. Constituição e segurança pública: os desafios do arranjo federal. JOTA, May 31, 2018, Available at: <https://www.jota.info/opiniao-e-analise/ artigos/constituicao-seguranca-publica-31052018\#_ftnref2>. Retrieved Jun. 11, 2018.

${ }^{70}$ Law no. 6.683, of August 28, 1979 (BRAZIL. Lei n. 6.683, of August 28, 1979. Concede Anistia e dá outras providências. Diário Oficial da União, Brasília, DF, Aug. 28, 1979 Available at: <http://www.planalto.gov.br/ccivil_03/ leis/L6683.htm?TSPD_101_R0=aebf6bccc0e5fOf6f1 ef8655f44456e3n3300000000000000003f92b0bfffff000000 
Such a mixed nature - combining, on one hand, a relative control over the transition by powerful groups and its continuous influence over the new regime with, on the other hand, a renewed democratic project and a stark reaction against authoritarianism from groups heavily active during the Constituent Assembly - reflected itself on the Constitution, whose very text shows well how this balance between democratic breakthroughs and compromises to keep untouched much of the past has been embedded in the Brazilian democracy. ${ }^{71}$

The Amnesty Law, its interpretation and enforcement are good examples of a past that insists to remain in place. Although the 1988 Constitution can be understood as an important reaction against authoritarian rule whose legitimacy was achieved during the constituent process due to the enormous participation of the civil society, the Supreme Court upheld the Amnesty Law as constitutional in the judgment of Allegation of Disobedience of a Fundamental Precept (Arguição de Descumprimento de Preceito Fundamental - ADPF) no. 153. The Court declared, among many other confusing arguments, that the Constitution was part of a "block of constitutionality" inaugurated by Constitutional Amendment no. 26 to the 1967 dictatorial Constitution, and, considering that such an Amendment did not revoke the law (it would have confirmed it instead), amnesty as enacted by the military should be deemed as compatible with the democratic constitutional order. ${ }^{72}$

More than a problem of constitutional compatibility, Raphael Peixoto de Paula Marques explains that it is a question of historical interpretation that is still in dispute and whose significance is enormous. ${ }^{73}$ We think it is fair to say that reinterpreting the whole social struggle for amnesty, reassessing the Amnesty Law and recasting the his-

$00000000000000000000005 b 2 b 171 a 006802 c d 5 f>$. Retrieved Jun. 12, 2018). It has long been viewed as a legal instrument devoted to protecting (governmental) perpetrators of heinous crimes committed during the dictatorship. It was upheld as constitutional by the Supreme Court in 2010 in the decision of an allegation of disobedience of a fundamental precept (Arguição de Descumprimento de Preceito Fundamental - ADPF) no. 153, even though legal cases in the Supreme Court and in the Interamerican Court of Human Rights are still pending.

${ }^{71}$ Roberto Gargarella is a sharp critic of what he calls "mixed Constitutions". See GARGARELLA, Roberto. Latin American Constitutionalism, 1810-2010: The Engine Room of the Constitution, New York: Oxford University Press, 2013, p. 157-162. Though his theory works with the distinction between organic and dogmatic parts of the Constitution (the first one having the prevalence and partially determining the interpretation, the width and the depth of the new rights disciplined in the dogmatic part), it is possible to use it to understand the Brazilian Constitution. In its context, the past (more entrenched) has the upper hand in the definition of the future; it tends to suffocate what is new and to restrain provisions that could otherwise be used to change or at least destabilize the status quo.

${ }^{72} \mathrm{~A}$ detailed account of the logics behind the decision of ADPF no. 153 and a critic of the historical arguments used by the Court to justify it can be found at ACUNHA, Fernando José Gonçalves; BENVINDO, Juliano Zaiden. Juiz e Historiador, Direito e História: Uma Análise Crítico-Hermenêutica da Interpretação do STF sobre a Lei De Anistia. Novos Estudos Jurídicos, vol. 17, n. 2, p. 185-205, May/Aug. 2012, Available at: <https://siaiap32. univali.br/seer/index.php/nej/article/view/3967/2310 >. Retrived Jun. 14, 2018.

${ }^{73}$ MARQUES, Raphael Peixoto de Paula. Anistia nos 30 anos da Constituição de 1988: passado, presente, futuro. JOTA, Jun. 14, 2018. Available at: <https://www.jota.info/opiniao-e-analise/artigos/anistia-nos-30-anos-daconstituicao-de-1988-passado-presente-futuro-14062018>. Retrieved Jun. 12, 2018. 
torical events of the 1960's, 1970's and 1980's is an essential task to understand how the country sees itself and its own past; it is also very important to explain to present generations why such a past cannot return. As the author writes (free translation),

In this context, one could ask about the future of amnesty. The $30^{\text {th }}$ anniversary of the 1988 Constitution may be a proper moment to reopen this debate. Recover the meaning of that social struggle for amnesty is an option to reaffirm the commitment to liberty and equality, principles that lie in the foundations of our constitutional text. At the institutional level, the debate remains open. There are pending lawsuits within the Supreme Court (ADPF no. 153 and 320) and the Interamerican Court of Human Rights (Vladmir Herzog case). Thereby, it is still necessary to deconstruct traditional metaphors about amnesty, (re)discussing and critically confronting the historical interpretation adopted by the Supreme Court about our past and the meaning of the 1988 Constitution.

As it is the case of amnesty, history must always be a central theme when we discuss the meaning of the Constitution, especially on the verge of its $30^{\text {th }}$ Anniversary. If the democratic text of 1988 is to be deemed as the main guide to the Brazilian society and to adequately perform its function as a settler of the parameters within which political struggles must be resolved, Brazilians need to pay attention to its own past and to the foundations of their three-decade-old democracy as a way to avoid regression and authoritarianism.

\section{CONCLUSION}

No one can deny that, after over thirty years of democratic life, Brazil has substantially changed for the better. The woes and evils that have long unsettle the Brazilian democracy are, however, still a hallmark of its constitutionalism: high rates of social and regional inequalities, entrenched social violence, and a political system that is unable to respond as legitimate representative of the people. In a sense, this conclusion illustrates the fact that a Constitution does matter - after all, no one will deny that a democratic transition that turned out to be a constitutional transition represents not only a symbolic achievement of a new era in Brazilian social life, but also serves as a reminder that, no matter what, the path towards democracy has to move forward towards more democracy and not the other way around. The authoritarian ghosts that up until now haunts the Brazilian reality, though inevitable due to the compromises that underpin it and the practices that stubbornly replicate the past into the very present, have at least to be disclosed and, as such, challenged by a learning process ${ }^{74}$ that only a militant memory is capable of making us aware of.

\footnotetext{
${ }^{74}$ See HABERMAS, Jürgen. Constitutional Democracy: a Paradoxical Union of Contradictory Principles? Political Theory, vol. 29, n. 6, p. 766-781, Dec. 2001.
} 
Constitutions - Przeworski had already said it -, "are neither sufficient nor necessary for democracy to survive, ${ }^{175}$ and can be easily reversed to become a tool to jeopardize democracy. ${ }^{76}$ Moreover, as the experiences of Brazil and Egypt have shown us, popular movements can be used both to foster change and to defend the status quo. As they can lead to transforming realities by channeling demands into the political realm, they can also lead to co-opting these very demands in order to create a simulacrum of the change in favor of those who do not want any change. Constitutions thereby need more than the belief in its own capacity of democratizing a reality. It is a parchment ${ }^{77}$ that aims to crystallize the future in the present, the promise in the law, ${ }^{78}$ but it is no magic. When we celebrate the thirty years of the Brazilian Constitution, those ripening years that separate rebelliousness from wisdom, it is time for a call for a reflection on where we wish to stand in the following thirty years. And, for that, if it is to keep alive the democracy we have so hardly achieved despite its shortcomings, those following thirty years must be forward-looking while challenging the ghosts our memory cannot ever just let them go.

\section{REFERENCES}

'ARAFA, Mohamed A. The Unexpected Trials of Egyptian Leaders: Is It a Question of Law or Politics? US China Law Review, vol. 12, n. 6, p. 467-487, 2015.

'ARAFA, Mohamed A. Towards a Culture of Accountability: A New Dawn for Egypt. Phoenix Law Review, vol. 5, issue 1, p. 1-39, 2011.

'ARAFA, Mohamed A. Whither Egypt? Against Religious Fascism and Legal Authoritarianism: Pure Revolution, Popular Coup, or a Military Coup D'État? Indiana International \& Comparative Law Review, vol. 24, n. 4, p. 859-897, 2014.

ABDEL-MALEK, Anouar. Egypt: Société Militaire. Paris: Editions de Seuil, 1962.

ACEMOGLU, Daron; ROBINSON, James. A. Economic Origins of Dictatorship and Democracy. Cambridge: Cambridge Univ. Press, 2006.

ACUNHA, Fernando José Gonçalves; BENVINDO, Juliano Zaiden. Juiz e Historiador, Direito e História: Uma Análise Crítico-Hermenêutica da Interpretação do STF sobre a Lei De Anistia. Novos Estudos Jurídicos, vol. 17, n. 2, p. 185-205, May/Aug. 2012, Available at: <https://siaiap32.univali. br/seer/index.php/nej/article/view/3967/2310>. Retrived Jun. 14, 2018.

${ }^{75}$ PRZEWORSKI, Adam. Why Democracy Survives in Affluent Societies? New York, Jan. 20, 2001, p. 18. Available at: <http://www.nyu.edu/gsas/dept/politics/seminars/whydemt.pdf $>$. Retrieved Jun. 14, 2018.

${ }^{76}$ LANDAU, David; DIXON, Rosalind. Constraining Constitutional Change. Wake Forest Law Review, vol. 50, p. 859-890, 2015.

${ }^{77}$ LEVINSON, Daryl J. LEVINSON, Daryl L. Parchment and Politics: The Positive Puzzle of Constitutional Commitment. Harvard Law Review, vol. 124, n. 3, p. 657-746, Jan. 2011, at p. 657.

${ }^{78}$ DERRIDA, Jacques. Force of Law: The Mystical Foundation of Authority. Cardozo Law Review, vol. 11, 1990. 
AGÜERO, Felipe. Institutions, Transitions and Bargaining: Civilians and the Military in Shaping Post-Authoritarian Regimes. In PION-BERLIN, David; (ed.). Civil-Military Relations in Latin America: Analytical Perspectives. Chapel Hill: University of North Carolina Press, 2001, p. 194-222.

ALBERT, Richard; BENVINDO, Juliano Zaiden; RADO, Klodian; ZHILLA, Fabian. Constitutional Reform in Brazil: Lessons from Albania? Revista de Investigações Constitucionais, vol. 4, n. 3, p. 11-34, set./dez. 2017.

AMAR, Paul. Why Mubarak is Out. In: HADDAD, Bassam; BSHEER, Rosie; ABU-RISH, Ziad (ed.). The Dawn of the Arab Uprisings: End of an Old Order? London: Pluto Press, 2012, p. 83-90.

AVRITZER, Leonardo. Civil Society in Brazil: From State Autonomy to Political Interdependency. Belo Horizonte, [s.n.], 2009.

AVRITZER, Leonardo. Participatory Institutions in Democratic Brazil. Washington: Wilson Press Johns Hopkins, 2009.

BARBOSA, Leonardo Augusto de Andrade. História Constitucional Brasileira: Mudança Constitucional, Autoritarismo e Democracia no Brasil Pós-1964. Brasília, Biblioteca Digital da Câmara dos Deputados, 2012,

BARROSO, Luís Roberto; BENVINDO, Juliano Zaiden; OSÓRIO, Aline. Developments in Brazilian Constitutional Law: The Year 2016 in Review. International Journal of Constitutional Law, vol. 15, n. 2, p. 495-505, June 30, 2017. Available at: <https://doi.org/10.1093/icon/mox038>. Retrieved Jun. 11, 2018.

BENVINDO, Juliano Zaiden. The Forgotten People in Brazilian Constitutionalism: Revisiting Behavior Strategic Analyses of Regime Transitions, International Journal of Constitutional Law, vol. 15, issue 2, p. 332-357, Apr. 2017.

BENVINDO, Juliano Zaiden; ACUNHA, Fernando José Gonçalves. Brazilian Democratic Decay and the Fear of the People, International Journal of Constitutional Law Blog, [s.l.], Jun. 24, 2017. Available at: <http://www.iconnectblog.com/2017/06/brazilian-democratic-decay-and-the-fear -of-the-people/>. Retrieved May 30, 2018.

BENVINDO, Juliano Zaiden; ACUNHA, Fernando José Gonçalves. Tempos na atuação da jurisdição constitucional: A interpretação inicial do STF a respeito do Mandado de Injunção e as oportunidades que não voltam In: PAIXÃO, Cristiano; MARTINS, Argemiro Cardoso Moreira (org.). Os tempos do direito: diacronias, crise, historicidade. São Paulo, Max Limonad, 2018 (forthcoming).

BILENKY, Thais. Forças Armadas lideram confiança da população; Congresso tem descrédito. Folha de S. Paulo, Jun. 24, 2017. Caderno Poder. Available at: https://www1.folha.uol.com.br/ poder/2017/06/1895770-forcas-armadas-lideram-confianca-da-populacao-congresso-tem-descredito.shtml Retrieved Jun. 5, 2018.

BILLER, David; DOUGLAS, Bruce. The Donald Trump of Brazil' Soars in the Polls. Bloomberg, Oct. 13, 2017. Politics. Available at: <https://www.bloomberg.com/news/articles/2017-10-13/ex-armycaptain-rises-in-brazil-polls-as-threat-to-the-corrupt>. Retrieved June 9, 2018. 
BRAZIL. Ato Institucional n. 2, of October, 27, 1965. Mantem a Constituição Federal de 1946, as Constituições Estaduais e respectivas Emendas, com as alterações introduzidas pelo Poder Constituinte originário da Revolução de 31.03.1964, e dá outras providências. Diário Oficial da União, Brasília, DF, Oct. 27, 1965. Available at: <http://www.planalto.gov.br/ccivil_03/ait/ait-02-65.htm>. Retrieved Jun. 5, 2018.

BRAZIL. Constituição da República Federativa do Brasil, of October 5, 1988. Diário Oficial da União, Brasília, DF, Oct. 5, 1988. Available at: <http://www.planalto.gov.br/ccivil_03/constituicao/ constituicao.htm>. Retrieved Jun. 12, 2018.

BRAZIL. Constituição da República Federativa do Brasil, of October 5, 1988. Diário Oficial da União, Brasília, DF, Oct. 5, 1988. Available at: <http://www.planalto.gov.br/ccivil_03/constituicao/ constituicao.htm>. Retrieved Jun. 12, 2018.

BRAZIL. Lei n. 6.683, of August 28, 1979. Concede Anistia e dá outras providências. Diário Oficial da União, Brasília, DF, Aug. 28, 1979 Available at: <http://www.planalto.gov.br/ccivil_03/leis/ L6683.htm?TSPD_101_R0=aebf6bccc0e5fof6f1 ef8655f44456e3n3300000000000000003f92b0bfffff00000000000000000000000000005b2b171a006802cd5f>. Retrieved Jun. 12, 2018.

BUARQUE, Daniel. Crise da elite política ajuda a corroer democracia, diz professor de Harvard. Folha de S. Paulo, Londres, Jun. 6, 2018. Mundo. Available at: <https://www1.folha.uol.com.br/ mundo/2018/06/crise-da-elite-politica-ajuda-a-corroer-democracia-diz-professor-de-harvard. shtml?utm_source=newsletter\&utm_medium=email\&utm_campaign=newsfolha $>$. Retrieved Jun. 10, 2018.

BUNCE, Valerie. Comparative Democratization: Big and Bounded Generalizations. Comparative Political Studies, vol. 33, issue 6-7, p. 703-734, 2000.

CARVALHO, Alessandra. As Atividades Político-Partidárias e a Produção de Consentimento durante o Regime Militar Brasileiro. In: ROLLEMBERG, Denise; QUADRAT, Samantha V. (org.). A Construção Social dos Regimes Autoritários: Legitimidade, Consenso e Consentimento no Século XX - Brasil e América Latina. Rio de Janeiro: Civilização Brasileira, 2011, p. 219-250.

COOK, Steven A. Ruling but not Governing: The Military and Political Development in Egypt, Algeria and Turkey. Baltimore: Johns Hopkins University Press, 2007.

CORPORACIÓN LATINOBARÓMETRO. Informe 2017. Buenos Aires: Corporación Latinobarómetro, 2018. Available at: <http://www.latinobarometro.org/latNewsShow.jsp>. Retrieved May 31, 2018. DERRIDA, Jacques. Force of Law: The Mystical Foundation of Authority. Cardozo Law Review, vol. 11,1990

DIAMOND, Larry J. Thinking about Hybrid Regimes. Journal of Democracy, vol. 13, n. 2, p. 21-35, Apr. 2002.

EDITORIAL BOARD. Acting Out of Weakness, Sissi Launches Another Crackdown, Washington Post, The Post's View, June 1, 2018. Available at: <https://www.washingtonpost.com/opinions/ 
global-opinions/egypt-is-being-run-by-a-jailer/2018/06/01/fa436c0c-64f5-11e8-99d2-0d678ec08c2f_story.html?utm_term=.0b037f4bb5f9>. Retrieved Jun. 5, 2018.

EL-DIN, Gamal Essam. How Did Muharak's Last PM Make it to Egypt's Second Round of Presidential Elections? Jadaliyya, May 26, 2012. Available at: <http://www.jadaliyya.com/Details/26064/HowDid-Mubarak\%60s-Last-PM-Make-It-To-Egypt\%60s-Second-Round-of-Presidential-Elections >. Retrieved Jun. 7, 2018.

EL-GHOBASHY, Mona. Egyptian Politics Upended. Middle East Research and Information Project, 20 Aug. 2012, Available at: <https://www.merip.org/mero/mero082012>. Accessed: 7 Jun. 2018.

EL-HAMALAWY, Hossam. Morsi, SCAF, and the Revolutionary Left. Jadaliyya, Jul. 1, 2012. Available at: <http://www.jadaliyya.com/Details/26430/Morsi,-SCAF,-and-the-Revolutionary-Left>. Retrieved Jun. 7, 2018.

FAUSTO, Boris. A Concise History of Brazil. Cambridge: Cambridge University Press, 1999.

FITCH, John Samuel. The Armed Forces and Democracy in Latin America. Baltimore: Johns Hopkins University Press, 1998.

GARGARELLA, Roberto. Latin American Constitutionalism, 1810-2010: The Engine Room of the Constitution, New York: Oxford University Press, 2013.

GUERRA, Maria Pia. Constituição e segurança pública: os desafios do arranjo federal. JOTA, May 31, 2018, Available at: <https://www.jota.info/opiniao-e-analise/artigos/constituicao-seguranca -publica-31052018\#_ftnref2>. Retrieved Jun. 11, 2018.

HABERMAS, Jürgen. Constitutional Democracy: a Paradoxical Union of Contradictory Principles? Political Theory, vol. 29, n. 6, p. 766-781, Dec. 2001.

HAMID, Shadi. The Muslim Brotherhood's New Power in Egypt's Parliament. Brookings, Dec. 23, 2011, Available at: <https://www.brookings.edu/opinions/the-muslim-brotherhoods-new-power -in-egypts-parliament/>. Retrieved Jun. 5, 2018.

HAMZAWY, Amr. Egypt's Anti-Protest Law: Legalizing Authoritarianism. Al-Jazeera, Nov. 24, 2016. Available at: <https://www.aljazeera.com/indepth/features/2016/11/egypt-anti-protest-law-legalising-authoritarianism-161107095415334.html>. Retrieved Jun. 5, 2018.

HELMKE, Gretchen; RIOS-FIGUEROA, Julio. Courts in Latin America. Cambridge: Cambridge University Press, 2011.

HIRSCHL, Ran. Comparative Matters: The Renaissance of Comparative Constitutional Law. New York: Oxford University Press, 2014.

HUNTER, Wendy. Politicians Against Soldiers: Brazil. Comparative Politics, vol. 27, n. 4, p. 425-443, Jul. 1995.

KANDIL, Hazem. Soldiers, Spies, and Statesmen: Egypt's Road to Revolt. London:Verso, 2014. 
KOERNER, Andrei. Os tempos da ordem constitucional - controle da constitucionalidade e continuidade legal na transição democrática no Brasil. In: SEMINÁRIO INTERNACIONAL "OS TEMPOS DO DIREITO: DIACRONIAS, CRISE, HISTORICIDADE", Brasília, 2016, p. 1-12.

LANDAU, David. Abusive Constitutionalism. University of California-Davis Law Review, vol. 47, p. 189-260, 2013.

LANDAU, David; DIXON, Rosalind. Constraining Constitutional Change. Wake Forest Law Review, vol. 50, p. 859-890, 2015.

LEVINSON, Daryl J. LEVINSON, Daryl L. Parchment and Politics: The Positive Puzzle of Constitutional Commitment. Harvard Law Review, vol. 124, n. 3, p. 657-746, Jan. 2011.

MAINWARING, Scott. Grass Roots Popular Movements and the Struggle for Democracy: Nova Iguaçu, 1974-1985. In: STEPAN, Alfred (ed.) Democratizing Brazil. New York: Oxford University Press, 1989.

MAINWARING, Scott. Urban Popular Movements, Identity, and Democratization in Brazil. Comparative Political Studies, vol. 20, issue 2, p. 131-159, July 1987, at p. 146-155. Available at: <https:// doi.org/10.1177/0010414087020002001>. Retrieved Jun. 5, 2018.

MARQUES, Raphael Peixoto de Paula. Anistia nos 30 anos da Constituição de 1988: passado, presente, futuro. JOTA, Jun. 14, 2018. Available at: <https://www.jota.info/opiniao-e-analise/artigos/ anistia-nos-30-anos-da-constituicao-de-1988-passado-presente-futuro-14062018>. Retrieved Jun. 12, 2018.

NAVARRO, Zander. Democracy, Citizenship and Representation: Rural Social Movements in Southern Brazil 1978-1990. Bulletin of Latin American Research, vol. 13, n. 2, p 129-154, May 1994.

PAIXÃO, Cristiano. 30 anos: crise e futuro da Constituição de 1988. JOTA, [s.I.], May, 3 2018. Available at: <https://www.jota.info/opiniao-e-analise/artigos/30-anos-crise-e-futuro-da-constituicaode-1988-03052018>. Retrieved Jun. 5, 2018.

POWER, Timothy J.; TAYLOR, Matthew M. Accountability Institutions and Political Corruption in Brazil. In POWER, Timothy J.; TAYLOR, Matthew M. (ed.) Corruption and Democracy in Brazil: The Struggle for Accountability. Notre Dame: University of Notre Dame Press 2011.

PRZEWORSKI, Adam. Democracy and the Market: Political and Economic Reforms in Eastern Europe and Latin America. Cambridge: Cambridge University Press, 1991.

PRZEWORSKI, Adam. Why Democracy Survives in Affluent Societies? New York, Jan. 20, 2001, p. 18. Available at: <http://www.nyu.edu/gsas/dept/politics/seminars/whydemt.pdf $>$. Retrieved Jun. 14, 2018.

SAYIGH, Yezid. Above the State: The Officer's Republic in Egypt. Carnegie Middle East Center, Aug. 1, 2012. Available at: <http://carnegie-mec.org/2012/08/01/above-state-officers-republic-in -egypt-pub-48972>. Retrieved Jun. 7, 2018. 
SKIDMORE, Thomas E. Brazil: Five Centuries of Change. 2 ed. New York: Oxford University Press, 2009.

SKIDMORE, Thomas E. Politics in Brazil, 1930-1964: An Experiment in Democracy. New York, Oxford Univ. Press, 1967.

SKINNER, Quentin. Meaning and Understanding in the History of Ideas, History and Theory, [s.I.], vol. 8, n. 1, p. 3-53, 1969.

STEPAN, Alfred. Paths towards Redemocratization: Theoretical and Comparative Considerations. In: O'DONNELL, Guillermo; SCHMITTER, Philippe C.; WHITEHEAD, Laurence. Transitions from Authoritarian Rule: Comparative perspectives, Baltimore: Johns Hopkins University Press, 1986, p. 64-84.

TAREK, Sherif. Egypt's Islamists Dominate Tahrir Square's Dense Friday. Ahram Online, Nov. 18, 2011. Available at: <http://english.ahram.org.eg/NewsContent/1/64/26902/Egypt/Politics-/ Egypts-Islamists-dominate-Tahrir-Squares-dense-Fri.aspx>. Retrieved Jun. 8, 2018.

THE ECONOMIST. The Economist Intelligence Unit's Democracy Index. [s.I.], [2018?]. Available at: <https://infographics.economist.com/2018/Democracylndex>. Retrieved Jun. 10, 2018. 